\title{
NMES
}

New Middle Eastern Studies

ISSN: 2051-0861

Publication details, including guidelines for submissions:

https://journals.le.ac.uk/ojs1/index.php/nmes

\section{The Palestine Policy of the US before the Israel Lobby}

Author(s): Selin M. Bölme

To cite this article: Bölme, Selin M. (2018) "The Palestine Policy of the US before the Israel Lobby", New Middle Eastern Studies 8 (2), pp. 5-26.

Online Publication Date: 9 January 2019

\section{Disclaimer and Copyright}

The NMES editors make every effort to ensure the accuracy of all the information contained in the journal. However, the Editors and the University of Leicester make no representations or warranties whatsoever as to the accuracy, completeness or suitability for any purpose of the content and disclaim all such representations and warranties whether express or implied to the maximum extent permitted by law. Any views expressed in this publication are the views of the authors and not the views of the Editors or the University of Leicester.

Copyright New Middle Eastern Studies, 2019. All rights reserved. No part of this publication may be reproduced, stored, transmitted or disseminated, in any form, or by any means, without prior written permission from New Middle Eastern Studies, to whom all requests to reproduce copyright material should be directed, in writing.

\section{Terms and Conditions}

This article may be used for research, teaching and private study purposes. Any substantial or systematic reproduction, re-distribution, re-selling, loan or sub-licensing, systematic supply or distribution in any form to anyone is expressly forbidden.

The publisher does not give any warranty express or implied or make any representation that the contents will be complete or accurate or up to date. The accuracy of any instructions, formulae and drug doses should be independently verified with primary sources. The publisher shall not be liable for any loss, actions, claims, proceedings, demand or costs or damages whatsoever or howsoever caused arising directly or indirectly in connection with or arising out of the use of this material. 


\title{
The Palestine Policy of the US before the Israel Lobby
}

\author{
Selin M. Bölme*
}

\begin{abstract}
In their well-known book, The Israel Lobby, John J. Mearsheimer and Stephen M. Walt argue that the Israel lobby has a significant influence on American policy towards the Middle East. As a consequence of Israeli lobbying, US-Israeli relations warmed by late 1950s and the United States became more committed to protecting Israel's interests. In my article, I analyse the policy of the US towards the Palestinian question before the Israel lobby gained that influence on US foreign policy, and I try to understand the making of American policy during the establishment of Israel. I also examine the factors that shaped the American policy and focus on Zionist lobbying in this period and question its influence. The period that I examine starts just before World War II under the presidency of Franklin D. Roosevelt (1933-1945) and I end the period with the recognition of Israel by the US under the presidency of Harry S. Truman (19451953). Many different domestic and foreign factors shaped the Palestine policy of the US in that period. However, I argue that even before the Israel Lobby was consolidated in the country, the Zionists had already gained a significant influence on American policy towards the Middle East region.
\end{abstract}

Keywords: Palestine; Israel Lobby; US Foreign Policy; Zionism; Truman; Roosevelt

\section{Introduction}

In their well-known book, The Israel Lobby, John J. Mearsheimer and Stephen M. Walt argue that the Israel lobby has a significant influence on American foreign policy, especially in the Middle East. According to them, this detrimental influence shapes the Middle East policy contrary to US national interests (Mearsheimer and Walt 2007: 49). The lobby, however, did not gain this influence in the White House and Congress overnight. When Israel was established in 1948, the US policymakers did not consider this weak and potentially vulnerable state as a strategic asset (Mearsheimer and Walt 2007: 7, 51). In 1953, Isaiah L. Kennen, the head of the American Zionist Council, reorganized the council and turned this foreign lobby group into a US lobbying organization and named it the American Zionist Committee for Public Affairs (which was later renamed "The American Israel Public Affairs Committee" - the AIPAC in 1959) (Mearsheimer and Walt 2007: 118). In a short time, the AIPAC became the head organization of the Israel Lobby. Mearsheimer and Walt (2007: 25,118 ) claim that, as a consequence of Israeli lobbying, US-Israeli relations warmed by late 1950s and the United States became more committed to protecting Israel's interests. The

*Selin M. Bölme; Assistant Professor, Institute of Middle East and Islamic Countries Studies, Marmara University, Istanbul, Turkey. Email: selin.bolme@gmail.com. 
Israel lobby's size and wealth grew considerably after the 1967 Arab-Israel (Six-Day) War and increased its influence during the John F. Kennedy and Lydon B. Johnson administrations. Since then, the US support towards Israel has increased significantly and turned into an unconditional one.

In my article, I analyse the policy of the US towards the Palestinian question before the Israel lobby gained the aforementioned influence on US foreign policy, and I try to understand the making of American policy during the establishment of Israel. I also examine the factors that shape the American policy and focus on Zionist lobbying in this period and question its influence. The period that I examine starts just before World War II under the presidency of Franklin D. Roosevelt (1933-1945). For before World War II, the United States' relations with the Middle East were very limited. Although commercial ties with the region can be traced to the early days of the Republic, the Middle East was viewed primarily as a British responsibility. And then I analyse the policies of Harry S. Truman (1945-1953). I end the period with the recognition of Israel by the US just before the establishment and consolidation of the power of the Israel Lobby.

\section{Roosevelt's Term: Defining the American Interest in Palestine}

Franklin Delano Roosevelt was elected president in 1932. He became President at the time of the "Great Depression" in the economy, a great debate in the foreign policy (between isolationists and interventionists), and the great World War II. Dealing with and balancing these three great issues mostly shaped the policy of his term. He won the elections by promising to take all necessary steps to end the economic crisis. During his first and second terms, implementing the New Deal program, which includes a series of economic reforms, was way more important than foreign policy issues. The last thing Roosevelt needed was a crisis in foreign policy while dealing with the Great Depression. President Roosevelt wanted to insulate his country from the world's troubles, at least until recovering the economy. Although he realized the impossibility of continuing an isolation policy, Jewish-related issues were not his priority. On the other hand, he was not unaware of the Zionist ideology. Roosevelt was close to the Zionist leaders of his time. Felix Frankfurter, who was a friend and advisor to him, had been an active member of the Zionist movement during World War I. Frankfurter had served in the Zionist delegation to the Paris Peace Conference in 1919. They met in their early careers. After Frankfurter was appointed as Associate Justice of the Supreme Court by Roosevelt in 1939, he refrained from making public statements yet never gave up the ideal to build a Jewish national homeland in Palestine. He continued to follow developments and got reports from Chaim Weizmann (Freund 1966: 35). The second important Zionist figure close to Roosevelt was Rabbi Stephen S. Wise, who was the Chair of the American Zionist Emergency Council. Roosevelt and Wise had been friends since Roosevelt's term as Governor of New York from 1929 to 1933. Wise actively supported Roosevelt during election campaigns in all terms (Halperin and Oder 1967: 332). He even protected him against accusations of being an anti-Zionist and not offering more than lip service to the Zionist search for a homeland (Medoff 2015).

The support of the Jewish community was always important for Roosevelt. He spent most of his political life in New York where half of the American Jews were living at the 
time. In 1930, he denounced discrimination against Jews and supported Palestine as a Jewish homeland while he was governor. Two years later, in his election campaign, he criticized anti-Semitism, becoming the first presidential candidate in US history to openly do so (Breitman and Lichtman 2013: 5). His brave support got him 82\% of the Jewish votes, which topped the ratio of support from all other religious or ethnic groups. ${ }^{1}$ In 1936 , just before the elections for Roosevelt's second term, the White House came under the pressure of numerous letters from Jewish organizations regarding the question of Jewish immigration into Palestine. ${ }^{2}$ Behind closed doors, Roosevelt gently worked to persuade the British government. In July, he instructed Ambassador Bingham, via Secretary of State Cordell Hull, to give a message as his personal view to the British government to postpone the plan which suspended Jewish immigration to Palestine. ${ }^{3}$ A month later, on 6 August 1936, Roosevelt took a bold step and publicly declared that the Jewish people had a right to settle in Palestine (Breitman and Lichtman 2013: 92). He made all these efforts not only to win the elections but also to solve the immigration problem that the US faced after Nazis came to power in Germany in 1933. In a meeting at the end of 1933, France and Britain demanded from the US to accept more refugees after Germany legalized eugenic sterilization. Joseph P. Chamberlain, the representative of Roosevelt, told the board that the US would tightly restrict immigration as long as economic hard times continued (Breitman and Lichtman 2013: 8283). In January 1937, by the efforts of Roosevelt, the Department of State loosened the restriction; however, in 1939, there was still an eleven-year waiting list for American visas and the American public and Congress still opposed easing immigration restrictions (Breitman 1996a: 132-133; Breitman and Lichtman 2013: 94, 102). Under these circumstances, Jewish immigration to any other place, particularly to Palestine, was a far better option than Jewish immigration to the US which could put the political future of Roosevelt at risk.

On the other hand, Washington did not want to intervene in British policy or challenge its hegemony and become part of a problem that could damage the relations among allies. Roosevelt and particularly the State Department thought that the Middle East, and hence Palestine, was primarily a British concern. Although Roosevelt never hesitated to express his sympathy regarding Zionist aims and support for establishing a Jewish national home in Palestine, he always avoided giving any official commitment to advance this goal. In 1938, Roosevelt replied to the letter of Senator Millard E. Tydings - who had concerns on British government's announcement about modification in the Balfour Declaration - as follows:

(...) I have on numerous occasions, as you know, expressed my sympathy in the establishment of a National Home for the Jews in Palestine and, (...) I understand, however, that under the terms of our convention with Great Britain regarding the Palestine Mandate we are unable to prevent modifications in the Mandate. The most we can do is to decline to accept as applicable to American interest any modifications affecting such interests unless we have given our assent to them. ${ }^{4}$

The British Government approved the modification on immigration, known as the White Paper, on March 1939. The Zionist movement faced a deadlock due to the British government's persistence in implementing the policy. Since the Balfour Declaration, Great Britain had been the centre of Zionist lobbying. Under the pressure of imminent war in 
Europe, Zionists did not have the efficient leverage to enforce British officials and decided to strengthen their base in the US (Parzen 1974: 32). Despite this unfavourable condition, Zionist leaders still believed that they could achieve their aims by getting full support from Roosevelt's administration. On 20 June 1939, Rabbi Solomon Goldman, the President of the Zionist Organization of America, sent a letter to Chaim Weizmann, the President of the World Zionist Organization. In his letter, Goldman wrote: "We have every reason to believe that the President has the finest understanding of, and the deepest sympathy with, our movement." Goldman claimed that Roosevelt was even considering a plan about moving two to three hundred thousand Arabs from Palestine into Iraq. This 300 million-dollar "Iraq plan" would be financed by Britain, France, the US and the world Jewry. Rabbi Goldman also described Secretary of State Cordell Hull as an unquestionable friend who was married to a Jewish woman. Wise was not worried about opposition which would be only found in lower positions at the State Department (cited in Halperin and Oder 1967: 320-321).

On the eve of World War II, in August 1939, the 21st Zionist Congress was held in Geneva and at the end of the Congress, the World Zionist Organization agreed to establish a special emergency committee in the US as the coordinating body of American Zionist organizations. The Emergency Committee for Zionist Affairs (ECZA) united four leading Zionist organizations of the time: the Zionist Organization of America, Hadassah, Poale Zion, and Mizrachi. Rabbi Stephan S. Wise was elected as the first Chairman of the Committee. The total number of members was 171,132 in 1940. Besides that, other small Zionist organizations were represented on the Committee by one non-voting observer (Bierbrier 1970: 83). As such, American Zionist Organizations became stronger, but their influence was still dependent on personal relations.

Zionist leaders were mostly disappointed when they faced Roosevelt's reluctance. After the war began, the US sided with Britain. In the early days of the war, Rabbi Stephen S. Wise asked for the arming of the Jews in Palestine to fight against the Nazis. Roosevelt refused to help, in accordance with the opinion of the State Department. British officials had more experience about the region and according to them; any expression of support for Zionism would anger the Arabs, possibly provoking them to support the Nazis. In his letter to Wise, Roosevelt explained the situation as such (Halperin and Oder 1967: 321-322):

In their Near Eastern campaign, the British must of necessity have the support of not only the Jews in Palestine, but also of a far greater number of Arabs in Transjordan, Sa'udi Arabia, and in the northern Arab states. The British are therefore obliged to handle their resources so as to maintain a maximum number of fighting men in the Near East and to enlist the support of all the peoples who live in that area.

Wise believed that this was not the President's opinion, but he was "hopelessly and completely under the domination of the English Foreign Office [and] the Colonial Office" (Halperin and Oder 1967: 321-322). It was not completely true. The State and War Departments had much influence on President. Each department had its own concerns, yet both were strongly opposed to active American assistance to European Jews. According to them, "Europe would always have its problems; the important thing now was to win the war" (Breitman 1996b: 123). After the United States officially entered the war on 8 December 1941, on different occasions, Secretary Cordell Hull and Under Secretary of State Sumner 
Welles advised Roosevelt to keep his statements colourless and to not show his support for Zionist organizations publicly (Halperin and Oder 1967: 322). Roosevelt followed this advice. In 1942, for instance, he decided not to send a message to the Jewish National Fund, which was raising funds for land-purchasing in Palestine, and rejected the request of the Zionist movement to give his name to one of the theatres of the Palestine (Jewish) Symphony Orchestra (Halperin and Oder 1967: 322; Medoff 2015).

On May 1942, ECZA took action and called an extraordinary conference (Bierbrier 1970: 86). Due to war conditions, it was impossible to gather the World Zionist Congress, so this meeting was the biggest such event of its time. All leading Zionist figures and organizations gathered at Biltmore Hotel in New York. The joint statement, issued at the end of the conference, sharply criticized the White Paper, and demanded unrestricted Jewish immigration and right to establish a Jewish Commonwealth:

The Conference urges that the gates of Palestine be opened; that the Jewish Agency be vested with control of immigration into Palestine and with the necessary authority for upbuilding the country, including the development of its unoccupied and uncultivated lands; and that Palestine be established as a Jewish Commonwealth integrated in the structure of the new democratic world. ${ }^{5}$

It was impossible to ignore the growing influence of Jewish movement. As a response, in late 1942, Roosevelt sent his personal envoy Lt. Col. Harold Hoskins to the Middle East to investigate the situation in the Arab World. Hoskins returned in early 1943. Roosevelt hoped to find a solution. Hoskins, however, reported that insistence on a Jewish state or Jewish Army might cause a very bloody conflict that could drag the Allies into it and most likely turn into a "third world war". In accordance with the report, the State Department proposed issuing a ban with the Allies to end all public discussion on Palestine until the end of the war. Given the strong anti-Zionist feeling among the Arabs, Washington chose to postpone the solution (Parzen 1974: 32). Roosevelt agreed with the War and State Departments on considering the feelings of the Arab and Muslim World. At the Anglo-American Refugee Conference in Bermuda in April 1943, when some delegates offered to send some Jewish refugees to North Africa, Roosevelt rejected this "extremely unwise" offer that would stimulate the Muslims in there (Medoff 2015; Breitman 1996b: 118). Strong objections of the State and War Departments shaped Roosevelt's decisions throughout 1943.

At that time, the American Zionist community was the largest and wealthiest Jewish group in the world. On the other hand, they still lacked a strong influence in American politics. Even Chaim Weizmann expressed his disappointment with the political passivity of the Emergency Committee during his visit to the US in 1942. After a year, in 1943, the Emergency Committee still had no office in Washington DC (Bierbrier 1970: 85). Zionist leaders understood that they could not get American support until they had leverage on administration, and they decided to reorganize the American Zionist movement. In September 1943, the American Jewish Conference was held in New York (Parzen 1974: 33). After the Conference, the Emergency Committee for Zionist Affairs (ECZA) was renamed as the American Zionist Emergency Council (AZEC), and Rabbi Abba Hillel Silver became the co-chair of the organization with Rabbi Stephan S. Wise (Bierbrier 1970: 86). 
The budget of the AZEC was increased vastly after the reorganization and this turned them into an important source of campaign donations in 1944 presidential elections. Roosevelt changed his policy towards Jewish demands under the pressure of the approaching elections. In late 1943, a War Refugee Board was established by his directive to help rescue the surviving Jews of Europe and make plans for their resettlement after the war (Breitman and Lichtman 2013: 4). The State Department also increased its efforts to convince the British government to loosen the White Paper. In a meeting with Wise and Weizmann, Roosevelt told them they would deal with the Palestine problem immediately. Moreover, the Under Secretary of State Sumner Welles told Wise and Weizmann that "the United States would be prepared to help financially in the development of the Jewish National Home" (Halperin and Oder 1967: 325). The competition between the Democrats and Republicans to get Jewish votes also influenced the Congress and they even started to consider pro-Zionist resolutions before the elections. The State and War Departments were firmly against that kind of commitment. The Secretary of State Cordell Hull urged Roosevelt to "refrain from making statements on Palestine during the campaign that might tend to arouse the Arabs or upset the precarious balance of forces in Palestine itself' (Medoff 2015). According to Hull, the passage of these resolutions would endanger American troops in combat areas and jeopardize the pipeline negotiations with Abdulaziz Ibn Saud - the Saudi King of Arabia. The oppositions of War and State Departments convinced the President and a majority of the members of the Congress - effectively stopping the action for any resolution (Halperin and Oder 1967: 331).

Despite many promises before the elections for helping the realization of a Jewish commonwealth in Palestine, immediately after the elections, Roosevelt informed Rabbi Wise that a Congressional resolution on the Palestine issue would be unwise (Halperin and Oder 1967: 335). Roosevelt thought that any kind of intervention to the situation in Palestine might start a "Holy Jihad" and risk the lives of American soldiers in the Middle East (Medoff 2015). It can be argued that he was never against a Jewish state in Palestine, but it was just not more important than the American interests. On the other hand, he was aware that the end of the war was close and if he did not take action before that, he would easily be blamed for doing almost nothing during the genocide against the Jews (later known as the "Holocaust") and that he might also lose his strong Jewish electoral support. He had already promised his Jewish friends to solve the Palestine problem before the end of the war. The Yalta Conference gave the President the chance he was looking for.

According to Roosevelt's plan, the Saudi King Abdulaziz Ibn Saud was the key figure. Roosevelt thought that he could find a solution by using personal diplomacy with the King (Koch 2016). If he could prove to the King that giving a small part of Palestine would not harm the interests of Arabs and had the King accepted the plan, it would be generally accepted by the rest of the Arab World (Koch 2016). The knowledge of American officials on Middle East was very limited at this time. They received almost all of their information from British officials and according to one of them, H. St. John Philby, the British adviser to Ibn Saud, American and British governments could persuade the King (Halperin and Oder 1967). On the other hand, this was a very sensitive issue for the US because of American oil interests in Saudi lands. Indeed, at the beginning of the war, Saudi oil was not a strategic asset although American oil companies had been operating in the region since 1938. In 
1941, for instance, when the State Department offered to include Saudi Arabia in the LendLease program, Roosevelt rejected it and replied, "This is a little far afield for us!" (cited in Lippman 2005: 3). After US officials discovered the importance of Middle Eastern oil in war because of increasing oil consumption, Roosevelt changed his point of view. In February 1943, he declared Saudi Arabia as vital to the defence of the United States and therefore eligible for financial aid (Lippman 2005: 3). Financial aid and oil interests were the two pillars of the relations between Saudi Arabia and the US. Roosevelt believed that developing relations and common interests could be helpful in finding a solution for the Palestine problem.

On 14 February 1945, after the end of the Yalta Conference, President Roosevelt and King Ibn Saud met at a US warship, the U.S.S. Quincy, for a two-day sailing on the Red Sea to Great Bitter Lake in the Suez Canal. The main reason for the meeting was the US oil interest, but Roosevelt also wanted to talk about the Palestine problem. Roosevelt thought that the Saudis really needed funds for recovering their economy and technologically developing their country and that kind of US support could persuade the King about giving up some Arab lands in Palestine (Koch 2016). During the meeting, Roosevelt offered economic aid and many projects that might improve the living standards in Saudi Arabia. At the end of the meeting, Roosevelt came to the point and said that he felt "a personal responsibility" for the Jewish victims of the Holocaust and asked the King for a solution. Ibn Saud listened to Roosevelt and spoke out his opinion (cited in Lippman 2005: 8):

\begin{abstract}
The Arabs would choose to die, rather than yield their land to the Jews (...). What injury have Arabs done to the Jews of Europe? It is the "Christian" Germans who stole their homes and lives (...). The Jews should return to live in the lands from which they were driven. The Jews whose homes were completely destroyed and who have no chance of livelihood in their homelands should be given living space in the Axis countries which oppressed them.
\end{abstract}

King Ibn Saud also refused the idea of resettling the Jews in Libya and said: "It would be unfair to the Muslims of North Africa" (cited in Lippman 2005: 8). Roosevelt did not want to harm the future of US-Saudi Relations due to their differing positions in the Palestine problem. He assured the King that "he would do nothing to assist the Jews against the Arabs and would make no hostile move against the Arab people" and that his government "would make no change to its basic policy in Palestine without full and prior consultation with both the Jews and Arabs" (Lippman 2005: 8). This promise determined the US policy for only the next few months until President Harry S. Truman got into power.

\title{
Truman's Term: Palestine as More of an Internal than an International Problem
}

In April 1945, Roosevelt died of a stroke and a few days later Harry S. Truman found himself as the President of the United States. World War II had just ended and there were a lot of pressing problems waiting to be solved. When he became President, he told reporters: "I felt like the moon, the stars, and all the planets had fallen on me" (cited in Freidel and Sidey 2006). Palestine, which would be under British mandate until 1948, was maybe not at the top of the list, but it was the most complicated one that Truman confronted. Despite the 
limitations of the White Paper, thousands of Holocaust survivors had illegally immigrated to Palestine during the war. The change in population distribution had already escalated the violence between Jews and Palestinian Arabs, and thousands of Jews were waiting to emigrate from Europe to establish "a new home". For Britain, it was impossible to deal with this crisis while struggling with deep economic problems in the aftermath of the War and the government decided to abandon Palestine when their mandate expired in 1948. While this new situation opened a vacuum of power for the Soviet Union in the region, it also increased the American concerns about accessing the vast oil fields in Arab countries (Devine, Watson and Wolz 2005: XI). Truman had to develop a solution immediately and his knowledge on Palestine, even Roosevelt's policies, was very little (Judis 2014). On the other hand, he had already given some promises to the Zionists. On 8 February 1944, while the public hearing on securing free entry of Jews to Palestine continued at the House of Representatives, Senator Truman wrote to David Dubinsky who was the president of the largest labour union and an influential Jew: "Great Britain and Russia absolutely necessary to us financing the war... although when the right time comes I am willing to help make the fight for a Jewish homeland in Palestine," (cited in Ovendale 2015: 150). He was pleased to get the support of influential Jews and he personally wanted to help Jews at displaced persons camps in Central Europe but as President, he also worried about the Arab reaction against Jewish immigration to Palestine. In her memoirs, Truman's daughter Margaret described the Palestine issue as "the most difficult dilemma of his entire administration" (cited in Radosh and Radosh 2009: XII).

Only six days after Truman became President, the Secretary of State Edward Stettinius sent a letter to the President and offered him a brief on Palestine before he faced the question. It was the first official contact of Truman with the problem. In his letter, Stettinius preinformed the President on the Zionist lobby's pressure which he would face soon and reminded him the necessity of handling the issue with the greatest care due to the vital interests of the US in the Middle East. ${ }^{6}$ Two weeks later, Joseph C. Grew, who was the Acting Secretary of State, sent another memorandum. While Grew repeated the policy, he emphasized the assurances that were given to Arabs by President Roosevelt (Truman 1956: 135). Truman, however, had different ideas and was annoyed by constant warnings from the State Department (Davidson 2010: 29). This was the beginning of the conflict between the White House and the State Department on the Palestine issue.

Many different domestic and foreign factors shaped Truman's Palestine policy. In the scholarly literature, some studies claim that Truman's policy was largely influenced by his humanitarian nature. According to Michael Benson (1997: IX), for instance, Truman's actions were "primarily on humanitarian, moral, and sentimental grounds, many of which were an outgrowth of the President's religious upbringing and his familiarity with the Bible". He supported a Jewish state because he believed in the Old Testament references to Palestine as a Jewish homeland and he wanted to give a chance to these mistreated people (1997: 8). In their book, A Safe Haven: Harry S. Truman and the Founding of Israel, Allis Radosh and Ronald Radosh also argued that Truman acted largely for humanitarian purposes and with religious motivation, and that other factors played an insignificant role in his policy (2009: VIII, 344). Lawrence Davidson was another observer who thought that the religious education of the President had a major impact on his judgments during his tenure (2010: 32). 
John J. Judis (2014) did not agree with the others on religious motives, but he accepted the strong moral streak in Truman's policy. According to him, Truman genuinely hated Nazis and sympathized with Jews as their victims, but he also wanted a solution that was fair to the Arabs as well as to the Jews. In his Memoirs, Truman stated his sympathy towards the "Jewish victims of Hitlerism". He described the US policy under his administration as "an American policy rather than an Arab or Jewish policy. It was American because it aimed at the peaceful solution of a world trouble spot. It was American because it was based on the desire to see promises kept and human misery relieved" (Truman 1956: 157). It is a fact that, at the beginning, Truman handled the Palestinian problem as a Jewish displaced person issue and viewed the immigration to Palestine as the only viable solution (Truman 1956: 136). On the other hand, describing Truman essentially as a moral person or a genuine humanitarian who was just interested in nothing but relieving holocaust victims has rather insufficient explanatory power.

As his first action, in July 1945, Truman sent a letter to Winston Churchill, asking him "to take steps to lift the restrictions of the White Paper on Jewish immigration into Palestine". 7 He also assigned Earl G. Harrison to investigate the conditions of displaced persons in Europe. Harrison submitted his report in a few months. In his report, Harrison recommended to the White House to allow reasonable numbers of Jewish refugees, at least 100,000, into the United States (Ovendale 1998: 69). However, it was not easy. Although the Holocaust had increased sympathy towards Jews in the American society, there was strong opposition in public and in Congress against the resettling of displaced person in the US because of economic concerns (McBride 2005: 29). A national survey conducted among American citizens in January 1946 indicated that only 5\% of Americans supported accepting more immigrants from Europe (Bierbrier 1970: 104). In August 1946, $72 \%$ of respondent answered "No" to a question that asked their support for a presidential plan about demanding Congress to allow more Jewish and European refugees to come to the US (Newport 2015). A few months later, according to Gallup's different polls taken in February and April in 1947, the percentage was still high; nearly $60-65 \%$ of Americans opposed bringing the displaced persons to the US (McBride 2005: 39). The American public opposition against accepting Jewish refugees created support for a Jewish state in Palestine instead. According to the American Institute of Public Opinion's poll in 1945, 76\% of the American public supported the settling of Jews in Palestine and another poll conducted by the US government indicated that $59 \%$ of the respondents favoured the creation of a Jewish state in Palestine while only 19\% were opposed (Bierbrier 1970: 103). Under these conditions, Truman knew, from the very beginning, that it was not easy to convince the Congress to relax the immigration quotas. He most likely would have lost the support of numerous American citizens if he had insisted on it. He had to find a solution that satisfied both the American and the Jewish electorate. Supporting the Jewish request for immigration to Palestine and giving all the responsibility to Britain was the best option for Truman.

In August 1945, Truman sent another letter to the new Prime Minister of Britain, Clement Attlee, and repeated the request on immigration quotas. ${ }^{8}$ Truman's initiation was contrary to Roosevelt's promises to consult the Arabs before taking any steps on Palestine. The State Department had already warned him about the sensitivity of the situation, which he had ignored. As a response to the US requests, on 13 November 1945, the British Foreign 
Secretary Ernest Bevin suggested the establishment of an Anglo-American Committee of Inquiry to examine the feasibility of Palestine for the European Jewish immigration and develop a solution. ${ }^{9}$ In April 1946, the committee submitted its report. It called Britain to permit the immigration of 100,000 European Jews to Palestine immediately and recommended a neither Jewish nor Arab state but two autonomous states with a strong, neutral government under international guarantees. Until the hostility disappeared between Jews and Arabs, the Committee recommended continuing under a United Nations trusteeship which effectively meant a British mandate. ${ }^{10}$ The recommendations of the Committee were rejected by Jews, Arabs, and the British government. On 12 June 1946, the American Zionist Emergency Council (AZEC) called a rally in Madison Square Garden against the report (Rosenfield 1947-1948: 245). Truman, however, was not in agreement with them. First, on 13 June, he sent a letter to King Ibn Saud to repair the damage in relations and regain his trust. In his letter, Truman assured him the immigration to Palestine would not constitute a change in the basic situation. ${ }^{11}$ Then he persuaded British partners and assigned the State Department official Henry Grady to draw a proposal for the partition of Palestine with British Deputy Prime Minister Herbert Morrison. In August 1946, the Morrison-Grady committee recommended a federated Palestine comprised of four cantons under the administration of a British high commissioner. Two cantons were under direct British control (including Jerusalem), one canton was Jewish, and one canton was Arab. ${ }^{12}$ A federated Palestine was the best solution according to Truman, and the State Department also supported the MorrisonGrady plan (Judis 2014). The Arabs and Jews, however, rejected the plan once again.

The Zionist lobby started an intense campaign against the proposal. In August, the President of American Jewish Community Joseph M. Proskauer and founder and President of the World Jewish Congress Nahum Goldmann asked Truman to consider the partitioning of Palestine into separate and independent Arab and Jewish states (Rosenfield 1947-1948: 248). Truman was also under the pressure of the AZEC, which turned into one of the strongest pressure groups in American history. According to the Secretary of Defence, Forrestal, and the Under Secretary of State, Lovett, in that term, American Zionists had gained the ability and power to put more pressure on the American government than any other interest group (Bierbrier 1970: 104). The Democrat Party officials and Truman's domestic advisers constantly warned Truman about Jewish support in coming elections. Although Truman preferred the Morrison-Grady plan for a federated Palestine (Judis, 2014), he could not stand against all that pressure from Zionist lobby organizations.

On 4 October 1946, on the eve of Yom Kippur, Truman made a public statement that announced US support for a "viable Jewish state in an adequate area of Palestine" and called the British government to open Palestine for the immigration of Jewish displaced persons in Europe. $^{13}$ The statement caused a crisis. Truman had informed neither the British Government ${ }^{14}$ nor the State Department about the content of the statement which was mostly written by his domestic advisors (Davidson 2010: 30-31). This statement meant a big change in the US basic policy and Truman did it without even consulting Saudi Arabia, which contradicted Roosevelt's hitherto assurances. The State Department officials thought that this change in policy endangered American oil interests in the Middle East and they had concerns about the immigration of what they perceived as "communist Jews" into Palestine, which would possibly increase the Soviet influence there. ${ }^{15}$ The Joint Chiefs of Staff were also 
against the partition as it could alienate the Arabs from the West (Overdale 1998: 71). On 15 October, King Ibn Saud sent a letter to Truman, reminding President of previous US promises and expressing his disappointment with the statement. ${ }^{16}$ Couple of months later, Amir Faisal, the Foreign Minister of Saudi Arabia, visited Truman to discuss the Palestine issue. As a solution for displaced persons in Europe, he suggested Truman take steps with the Congress to receive a considerable number of these people in the United States. ${ }^{17}$ Truman was fully aware of the disappointment of Saudis, but he had no intention to take a step back.

Despite his aforementioned public support and sympathy, Truman was neither a Christian Zionist nor a Philo-Semite as Judis rightly pointed out (Judis 2014). Although later he wrote in his Memoirs that "The American policy was designed to bring about, by peaceful means, the establishment of the promised Jewish homeland and easy access to it for the displaced Jews of Europe" (Truman 1956: 157), he did not support the idea of a Jewish state at the beginning. In his first meeting with Zionist group leaders, Rabbis Abba Hillel Silver and Stephen Wise, he told them that he categorically objected to a religious state - whether it is Catholic or Jewish. He also thought that establishing such a state would certainly cause a war in the Middle East (Judis 2014). According to his personal notes, he had even some negative thoughts on Jews. His longhand notes, written three months before he became president, revealed his doubts on Jewish beliefs: "The Jews claim God Almighty picked 'em out for special privilege... Fact is I never thought God picked any favorites". ${ }^{18}$ After spending nearly two years under the pressure of Zionist lobbying, on 21 July 1947, Truman wrote these sentences in his diary (Truman 1947):

The Jews, I find are very, very selfish. They care not how many Estonians, Latvians, Finns, Poles, Yugoslavs or Greeks get murdered or mistreated as D[isplaced] P[ersons] as long as the Jews get special treatment. Yet when they have power, physical, financial or political neither Hitler nor Stalin has anything on them for cruelty or mistreatment to the underdog. Put an underdog on top and it makes no difference whether his name is Russian, Jewish, Negro, Management, Labor, Mormon, Baptist he goes haywire. I've found very, very few who remember their past condition when prosperity comes.

When Truman's diaries came to light in 2003, it caused a shock in the Jewish community and some people even blamed Truman for being an anti-Semite. But according to most Truman biographers and historians, Truman was just a man who had grown up in a small MidWestern town and a product of his era, and these remarks did not make Truman an antiSemite (Goldenberg 2003). Truman's remarks reflected some of his prejudgments; on the other hand, these opinions never prevented his close relations with the Jewish community and the Zionist lobby.

From the start of his presidency, Truman felt the pressure of the Zionist lobby. Zionists or pro-Zionists were not only in formal lobbying organizations but also in the White House and the Congress. Throughout 1946, Truman received many letters from Democratic Party politicians that reminded him the importance of Jewish votes (McBride 2005: 33). Many political leaders from both political parties also announced their support for a Jewish state or a homeland in Palestine (Pops 2013: 5). Among these names, one stood out: Eleanor Roosevelt, the wife of former President F. D. Roosevelt. Eleanor Roosevelt was known for her efforts for social justice and the protection of minorities, and she was the first chair of the 
Human Right Commission (Kidd 2017: 4). She had great prestige and influence in the American society. From 1945 onwards, Eleanor Roosevelt dedicated herself to the creation of Israel. According to her, a sovereign state was the only solution to keep Jews safe from future harassments. Although she received warnings from the State Department that immigration of thousands of Jews from Europe to Palestine was likely to create another displacement in Palestine, she was blind to the Arab side of the problem. Her knowledge on Palestine or Arabs was very little and based on Oriental biases and prejudices. Eleanor Roosevelt even asked for lifting of the US arms embargo towards Palestine so that the "Jewish community in Palestine could be equipped to adequately fight the Arabs". Ironically, later, in December 1948, she read the Universal Declaration of Human Rights to the General Assembly of the United Nations (Kidd 2011: 107-111).

Truman's knowledge on the Palestine issue was mostly shaped by these people. Some of the pro-Zionists were working within the White House inner circle, such as White House domestic adviser Clark Clifford, his assistant Max Lowenthal, and Truman's Special Assistant for Minority Affairs David Niles. According to them, refugee Zionism would not lead to a war in Palestine and an American support for a Jewish state would not ruin the American relations with the Arabs (McBride 2005: 31). On 1 October 1946, Truman met with Max Lowenthal. Lowenthal's position was a Middle East expert but had never travelled to the Middle East and his knowledge on the region was very limited (Davidson 2010: 3132). On the other hand, he was an influential voice of the Zionist lobby and had supported Truman during his nomination as vice president (Rodash and Rodash 2009: 185-187). His opinion was important for the President. Lowenthal advised Truman to get authorization for admission of a large number of displaced persons in Palestine before the elections. According to him, if they succeeded, it would bury the Republican Party in the elections.

There was a sharp difference on the Palestine issue between Truman's advisers and the officials in State and Defence Departments. Secretary of Defence James Forrestal, most of the staff in the Defence Department and higher-ranking military officials thought that taking the side of Israel was a mistake (Pops 2013: 5). An Israel state most probably would be a weak state which could be easily defeated by Arabs, and in a hostile environment it would need American military support. From the military point of view, defending this state would drain American resources and lives (Perry 2010). The only thing that really mattered was Arab oil and the US should focus on its own interests. ${ }^{19}$ Forrestal was not alone. The Secretary of State George Marshall, his assistant Robert Lovett, the head of the State Department's Office of Near East and African Affairs Loy Henderson and subsequent foreign policy officers such as Dean Rusk, George Kennan, Dean Acheson, Paul Nitze and Edwin Wright shared most of Forrestal's concerns. State Department officials were strongly opposed to the creation of a Jewish state in Palestine. Supporting the establishment of a Jewish State would increase opportunities for the Soviet Union, endanger access to Middle East oil reserves and jeopardize US basing rights in the region. According to Henderson, the US had moral prestige in the Near and Middle East more than any other great power and it could lose this as a result of such a risky action. ${ }^{20}$ Moreover, it would lead to war and if the US took a firm stand in establishing a Jewish state in Palestine, this would cause anti-Americanism in the whole Middle East, and the Soviet Union would certainly take advantage of this situation. $^{21}$ 
However, according to the Department of Interior and Truman's domestic advisers, pro-Arab officials in the State Department were exaggerating the oil issue. Abe Fortas, the Under Secretary of Department of Interior, once said to Benjamin Azkin from AZEC that "even the oil companies hardly believe that strong American backing of Zionism would result in permanent endangering of American oil interests" (cited in Bierbrier 1970: 100). He was not wrong. At a very early stage, American Zionists were aware that the American oil companies could become a serious threat to Zionist aims. In November 1945, AZEC leaders met ARAMCO (Arabian American Oil Company) representatives to discuss the Palestine issue and their position. Although the view of the representatives was pro-Arab, they called themselves neutral on Zionism. More importantly, they thought that Saudi Arabia was more dependent on the US than vice versa and so they were not afraid that the Arabs could cause any serious damage on them (Bierbrier 1970: 100). Because of oil agreements, American loans and development projects on King's lands, since the Roosevelt administration, the relations between the two countries had been more complicated. While the US and Saudi officials were discussing the Palestine issue, they maintained their negotiations about projects, including the construction of a railroad from the Persian Gulf to Riyadh, water supply and electric power for Riyadh and Jidda, hospitals at Jidda and Taif, irrigation, and transportation. The approximate total coast of the projects was $\$ 15$ million, and it was covered by US loans. ${ }^{22}$ The Saudis simply had too much to lose. Under these conditions, the American Zionists did not have a real rival to challenge them in the making of American Middle East policy.

On 2 April 1947, Britain formally requested from the UN General Assembly to place the question of Palestine on the agenda and recommended the establishment of a special committee to prepare a report on the issue. In response to a British government request, the United Nations Special Committee on Palestine (UNSCOP) was established on 15 May 1947. There was political pressure on the Committee. During the summer of 1947, the Zionist lobby organized writing campaigns, rallies and media events to keep the refugee issue on global public agenda and get public support for an independent Jewish State (Evensen 1992: 27). Lobby members also increased the frequency of their visits to US officials. On 3 September 1947, the Committee announced its report and recommended termination of the British mandate over Palestine by summer 1948. It submitted two proposals to the General Assembly concerning the future government of Palestine. The first proposal, entitled the Majority Plan, recommended division of Palestine into a Jewish state, an Arab state, and Jerusalem. The second proposal, the Minority Plan, recommended one Federal union with Jerusalem as its capital. $^{23}$

Although the Plan for Partition did not offer Zionists everything they wanted, it was good enough to be accepted as a beginning step. For the Arab side, both plans that gave a part of Palestine to Jews were unacceptable. The situation was very complicated for the US administration. While violence was escalating in Palestine and the British government was preparing to leave the region, the State and Defence Departments were not sure about how to deal with the problem. The US approved the establishment of UNSCOP, but Secretary of State Marshall had some reservations. The best option in his mind was a temporary UN trusteeship to maintain the negotiations and force the sides to a truce (Pops 2013: 6-7). Opposition against partition was strong in the State Department. According to Henderson, 
partition was a "recipe for war" and, if the US supported partition, it would ensure long-term Arab hostility (Davidson 2010: 35). Truman, however, did not trust the aristocratic crowd of "striped-pants boys" at the State Department and their arguments on endangering American interests in the region. According to him, they had their priorities wrong (Davidson 2010: 29, 33). The UN partition of Palestine could open the way for peaceful collaboration between the Arabs and the Jews (Truman 1956: 156). Besides that, 65\% of Americans were in favour of the partition of Palestine and only 10\% were opposed (Saad 2017). Although Truman supported partition, he had some reservations on an independent Jewish State. He preferred the Morrison-Grady plan for a federated Palestine and from time to time blamed all sides for its abandonment (Judis 2014; Rodash and Rodash 2009: 177-178). Before the UN vote, he avoided openly advocating partition and on 24 November 1947, he instructed his staff and the UN delegation of the US to not put pressure on other delegations. Despite his instructions, behind closed doors, members of his own staff continued to work to assure enough support for the partition (Davidson 2010: 35-36).

On 29 November 1947, the partition plan was passed by the UN General Assembly and Resolution 181 divided Palestine into two states. The US announced its support for the Resolution. In a very short time, extensive clashes between Jews and Arabs on the ground turned into a civil war. The escalating violence in Palestine shocked Truman and caused a shift in his position (Pops 2013: 8). He did not want to send American troops to the region while the tension was rising between the US and Soviets because of the Berlin Crisis (Evensen 1992: 122). The American public was also against sending troops to enforce the UN partition plan (Judis 2014). On the other hand, it was impossible to implement the plan without using any force and it was most likely to result in uncontrolled warfare and chaos. In view of the continued turmoil, the State Department persuaded Truman on the possible unwanted results of partition. They started a search to find a way to abandon US support for partition and revive the idea of a United Nations trusteeship (Evensen 1992: 120). As a first step, on 5 December 1947, Marshall announced the implementation of an American arms embargo on the Middle East. To declare the new policy of the US at the UN Security Council meeting on partition plan, the State Department prepared a speech for the US ambassador to the UN Warren Austin. On 23 February 1948, Marshall sent the text of the speech to Truman and got his permission (Pops 2013: 9).

Truman's advisers, however, did not approve of the radical change in US policy. Niles did not believe that the support of the US to the partition plan would influence its relations with the Arabs. According to him, the Arabs "did not align themselves with the Kremlin. Nor has King Ibn Saud cancelled American oil concessions." Clifford shared the same viewpoint. As $90 \%$ of Saudi Arabia's revenues came from American royalties, they would not endanger the relations. In a memorandum in March 1948, he said that "the Arab states must have oil royalties or go broke," (cited in McBride 2005: 31). The difference in the Palestine policy turned into a battle between the White House and the State Department. According to State Department officials, Clifford, Niles and Truman's other advisers knew nothing about either foreign affairs or the Middle East and they provided wrong advice to the President. His own staff, however, had a huge influence on Truman. ${ }^{24}$ Despite Truman's agreement with the State Department to revive the UN trusteeship and not meet Zionist lobbyists in this term, on 
18 March 1948, Truman accepted Chaim Weizmann and assured him of US support for the partition. He did not inform the State Department about the meeting (Davidson 2010: 36-37).

On 19 March 1948, in General Assembly, the US ambassador to the UN, Warren Austin announced that the US would suspend partition and support temporary trusteeship. The speech caused a huge crisis. Zionist leaders reacted bitterly. Eleanor Roosevelt, who was a member of the US delegation to the United Nation, threatened to resign from the delegation (Kidd 2017: 4, 110). All these could damage Truman's image just before the elections. Against this reaction, Truman chose to blame the State Department's "third and fourth levels" for sabotaging his policy (Pops 2013: 10; Davidson 2010: 3) and declared the US support for the partition.

In the spring of 1948, the main question on the agenda was whether the US would recognize the State of Israel which would most likely be announced on 15 May 1948, after the end of the British Mandate. The State Department maintained its firm position and recommended not to recognize it. On 12 May 1948, Marshall clashed with Truman and Clifford openly in a meeting. Clifford said the US had made a moral commitment to the world's Jews that dated from Britain's 1919 Balfour Declaration and added that JewishAmericans were an important voting bloc and would favour the decision (Perry 2010). Clifford's existence in the meeting as a domestic adviser and his comments on a foreign policy issue annoyed Marshall. After the meeting, Marshall told Truman that "If the president were to follow Mr. Clifford's advice, and if I were to vote in the next election, I would vote against the president" (cited in Lilienthal 1999: 49). Marshall believed that Truman put winning the elections before American interests. Marshall once told Henderson that "Palestine had become more of an internal than an international problem". ${ }^{25}$ Like Marshall, Forrestal thought that Truman's Palestine policy was motivated by "squalid political purposes" (cited in Davidson 2010: 39). Because of their opposition, later, these two American War heroes were accused of being anti-Semites.

There is huge debate in the literature about the influence of Jewish votes in Truman's policy. John Snetsinger's book (1974) is at the centre of this discussion. In his book, Snetsinger claimed that Truman's re-election strategy ultimately shaped his Palestine policy. Snetsinger influenced many researchers. Davidson (2010: 30) also argued that Truman's approach to the issue was strongly influenced by his political desire to be elected president in 1948. On the other hand, a group of researchers (Michael Benson 1997; Judish 2014; Rodash and Rodash 2009) who explain Truman's policy with humanitarian causes criticized that approach. Judis (2014) claimed that Truman's “support for the right of the refugees to immigrate to Palestine reflected his moral conviction rather than any concern about electoral support." Although Snetsinger's research was based on limited sources and examined Truman's policy from a narrow point of view, he had a point. It is impossible to neglect the influence of elections as one of the factors that formulated Truman's policy. Although he was very serious about resolving the refugee issue, he also knew that his justifications on humanitarian grounds provided him the support of democrat electorates.

Truman might have been unprepared and inexperienced in foreign affairs when he first became President, but he had been in politics for a long time. Truman was first elected to public office as a county official in 1922, and then as a US Senator in 1934 (Freidel and Sidey 2006). He was keenly aware of the growing influence of Jewish votes. In 1947, more 
than 5 million Jews, nearly half of the Jewish World population, were living in the United States. Although Jews were estimated to constitute $3.66 \%$ of the total US population, they were living in key Electoral College states that were critical in elections. $46 \%$ of them were in New York and the rest of them were mostly in Pennsylvania (9\%), Illinois (8\%), Massachusetts (4\%) and California $(3.5 \%){ }^{26}$ The most important question is "were they unanimous in their support of a Jewish homeland in Palestine?". According to one opinion, they were (Devine, Watson and Wolz 2005: XI); according to others (Davidson 2010: 30), they were not, but the Zionist lobby had convinced Truman that all American Jews favoured a Jewish state in Palestine. Most likely, the lobby exaggerated the importance of the Jewish vote; however, Truman never asked for an independent research on Jewish electoral behaviour. It was not difficult to convince the President. The support of the Zionist lobby meant not only Jewish votes but also huge campaign donations. On the other hand, there was no influential Arab lobby or voting block against the Zionist lobby.

On 14 May 1948, the Provisional Government of Israel proclaimed the independent State of Israel. On the same day, without notifying the State Department, President Truman released a press statement that announced the recognition of the provisional Jewish government as the "de facto" authority of the new Jewish state. Despite the pressure of the Zionist lobby, Truman refused to accept de jure recognition before the elections in Israel, decided to maintain the arms embargo and did not recognize the extending borders of Israel that included occupied territories (Evensen 1992: 120). On the eve of the elections, however, further pressures came from Zionists to get the de jure recognition. They already had the support of Republican presidential candidate Thomas Dewey. In this context, the Zionists managed to get a promise from Truman. In 1948, Truman won the elections but lost in the New York State where the Jewish votes were most significant (McBride 2005: 34-36). The drop in Jewish support worried the newly elected President. On 31 January 1949, Truman extended American de jure recognition to Israel and as a symbolic gesture, announced the recognition of Transjordan on the same date (Devine, Watson and Wolz 2005: XIII). Despite his anger at Truman, King Ibn Saud did not cancel any agreements or take any actions against the US. Furthermore, in 1949, he accepted a full-fledged American military training program (Lippman 2005: 12). This meant a complete victory for Truman, his team, and the American Zionists seeking to establish the State of Israel in Palestinian territories.

\section{Conclusion}

Israel was not a strategic asset in US policy before the establishment of the Israel Lobby in the early 1950s. However, this does not mean that US policymakers had been free from all pressure in Middle East policy or free to put American interests first in their decisions before the Israel lobby joined the game. In that short period, between World War II and the establishment of the Israel Lobby, the American Zionists reorganized themselves, became the centre of the Zionist movement and gained significant influence on American politics. Particularly in Truman's period, the Zionist lobby's size and wealth grew so much that they became an important factor in America's Middle East policy. On the other hand, their influence was mostly dependent on their personal relations with the President, influential government officials, and pro-Zionist advisers. The State and Defence Departments' officials 
were strongly opposed to the creation of a Jewish state in Palestine in Roosevelt's and Truman's periods. According to them, American support for a Jewish state could ruin America's image and its relations with the Arabs, endanger American oil interests in the Middle East and increase opportunities for the Soviet Union in the region. Moreover, they did not want to put the lives of American soldiers in danger for the sake of a Jewish state while dealing with the Soviet Union in Europe.

In Roosevelt's period, State and War (Defence) Departments' advice and the British experience mostly shaped the Palestine policy. Following their advice, Roosevelt always considered the feelings of Arab people and the position of Arab leaders. Yet, Roosevelt's Palestine policy was a balancing policy. Under war conditions, he tried to balance different interests. He was close to the Jewish community and he genuinely wanted to find a solution to the Jewish immigration problem. For him, it was a responsibility as a human being against Germany's mass extermination policy. Furthermore, the support of the Jewish community as a voting bloc had become more important in his term. However, it did not mean that European Jews were welcome in the US. There was strong opposition in the American public against immigration. Due to economic concerns, Jewish immigration to Palestine was a far better option than Jewish immigration to the US. However, Roosevelt did not want to sacrifice US relations with Great Britain or Saudi Arabia for the establishment of a Jewish state in Palestine. To keep the balance among all sides, he occasionally offered rhetorical support for the Zionist goals, but he avoided giving any official commitment to advance them.

As it was for Roosevelt, many different domestic and foreign factors had shaped Truman's Palestine policy. Most of these factors were similar to those seen in Roosevelt's term. The US still had economic concerns and most of the American society was against Jewish immigration to the country. American oil interest was still the top agenda regarding the Middle East policy, and State and Defence Departments maintained their firm position against a Jewish State in Palestine. On the other hand, there were important differences between Roosevelt's and Truman's terms. One of them was the level of ability demonstrated by the Zionist lobby. In that period, the AZEC completed its transformation and turned into a well-organized, adequately financed organization with a highly motivated staff. They had supported Truman during his nomination as vice president, gaining strong political leverage on the administration. Most of the people working within the White House inner circle were Zionists or pro-Zionists. The definition of American interests in Palestine was changed by these people. They convinced the President that pro-Arab officials in the State Department were exaggerating the oil issue, and that Jewish-Americans as an important voting bloc were supporting a Jewish state in Palestine. The support of the Zionist lobby meant not only Jewish votes but also huge campaign donations and there was no influential Arab lobby or voting bloc against the Zionist lobby. Most likely, the lobby and Truman's advisers exaggerated the importance of the Jewish vote. On the other hand, they were right about Saudi Arabia's overwhelming dependency on the US. Saudi Arabia's silence against the US recognition of Israel proved that the Zionist lobby would not have a real rival in American politics. This valuable knowledge would shape the US Palestine Policy in the decades to come. 


\section{Notes}

1. "U.S. Presidential Elections: Jewish Voting Record (1916 - Present)," Jewish Virtual Library, https://www.jewishvirtuallibrary.org/jewish-voting-record-in-u-s-presidentialelections.

2. FRUS*, The Near East and Africa, Volume III, Document 533, The Chief of the Division of Near Eastern Affairs (Murray) to the Assistant Secretary of State (Moore), 18 November 1936.

3. FRUS, The Near East and Africa, Volume III, Document 519, The Secretary of State to the Ambassador in the United Kingdom (Bingham), 27 July 1936.

4. Letter on Palestine Situation, The public papers and addresses of Franklin D. Roosevelt, 14 October $1938 . \quad$ Accessed 5 August 2018. <https://quod.lib.umich.edu/p/ppotpus/4926315.1938.001?rgn=main;view=fulltext >

5. Zionist Congresses: The Biltmore Conference, 6-11 May 1942. Accessed 10 August $2018<$ https://www.jewishvirtuallibrary.org/the-biltmore-conference-1942>

6. Truman Papers, Edward Stettinius to Harry S. Truman, 18 April 1945, President's Secretary's Files, Palestine (1945-1947). Accessed 20 August 2018. <https://www.trumanlibrary.org/whistlestop/study_collections/israel/large/documents/ind ex.php?documentdate=1945-04-18\&documentid=2-5\&pagenumber=1 >

7. FRUS, The Near East and Africa, Volume III, Document 698, Memorandum by President Truman to the British Prime Minister (Churchill), 24 July 1945.

8. FRUS, The Near East and Africa, Volume III, Document 715, President Truman to the British Prime Minister (Attlee), 31 August 1945.

9. Statement on Palestine by British Foreign Secretary Bevin, 13 November 1945, Viewed 20 August 2018. <https://www.jewishvirtuallibrary.org/statement-on-palestine-by-britishforeign-secretary-bevin-november-1945>

10. Anglo-American Committee of Inquiry: Report to the United States Government and His Majesty's Government in the United Kingdom Lausanne, Switzerland, 20 April 1946. Accessed 20 August 2018.

11. FRUS, The Near East and Africa, Vol. VII, Document 505, President Truman to the King of Saudi Arabia, 13 July 1946.

12. Morrison-Grady Scheme (Plan for Provincial Autonomy, 1946. Accessed 21 August 2018 $<$ https://ecf.org.il/issues/issue/455>

13. Recognition of the State of Israel: Background, Accessed 21 August 2018 <https://www.trumanlibrary.org/whistlestop/study_collections/israel/large/index.php?acti on $=\mathrm{bg}>$

14. FRUS, The Near East and Africa, Vol. VII, Document 548, President Truman to the British Prime Minister (Attlee), 3 October 1946; FRUS, The Near East and Africa, Vol. VII, Document 549, The British Prime Minister (Attlee) to President Truman," [undated, 1946].

15. Recognition of the State of Israel: Background...

16. FRUS, The Near East and Africa, Vol. VII, Document 554, The King of Saudi Arabia (Abdul Aziz Ibn Saud) to President Truman, 15 October 1946. 
17. FRUS, The Near East and Africa, Vol. VII, Document 566, Memorandum by the Acting Secretary of State (Memorandum of Conversation Between the President and Amir Faisal, Foreign Minister of Saudi Arabia), 13 December 1946.

18. Longhand Note of President Harry S. Truman 1-5 June 1945. President's Secretary's Files. Accessed 18 August 2018.

<https://www.trumanlibrary.org/whistlestop/study_collections/trumanpapers/psf/longhan d/index.php?documentVersion=both\&documentid=hst-psf_naid735224-

01\&pagenumber=3https://www.trumanlibrary.org/whistlestop/study_collections/trumanp apers/psf/longhand/index.php?documentVersion=transcript\&documentid=hstpsf_naid735224-01>

19. Oral History Interview with Clark M. Clifford by Jerry N. Hess, 13 April 1971. Accessed 21 August $2018<$ https://www.trumanlibrary.org/oralhist/cliford2.htm\#95>

20. FRUS, The Near East and Africa, Vol. VIII, Document 711, Memorandum by the Director of the Office of Near Eastern and African Affairs (Henderson) to the Secretary of State, 24 August 1946.

21. Oral History Interview with Loy W. Henderson by Richard D. McKinzie, 14 June/ 5 July $\begin{array}{llll}1973 . & \text { Accessed } & 21 & \text { August }\end{array}$ <https://www.trumanlibrary.org/oralhist/hendrson.htm>; Oral history interview with Edwin M. Wright by Richard D. McKinzie, 26 July 1974. Accessed 21 August 2018. <http://www.trumanlibrary,org/oral- hi st/w right.htm>.

22. FRUS, The Near East and Africa, Vol. VII, Document 583, The Secretary of State to the Minister in Saudi Arabia (Childs), 22 October 1946; FRUS, The Near East and Africa, Vol. VII, Document 582, President Truman to the King of Saudi Arabia (Abdul Aziz). 3 October 1946.

23. United Nations Special Committee on Palestine: Report to The General Assembly, Official Records of The Second Session of The General Assembly, Supplement No.11, 3 September 1947. Accessed 19 August 2018.

24. Oral history interview with Edwin M. Wright.

25. Oral History Interview with Loy W. Henderson.

26. 'Statistics: Jewish Population (1947-1948)' The American Jewish Year Book, 49 (5708), 733-744.

\section{References}

*FRUS (Foreign Relations of the United States) Series, https://history.state.gov/historicaldocuments. Accessed 1 August 2018.

Bass, Warren (2003) Support Any Friend: Kennedy's Middle East and the Making of the U.S.-Israel Alliance (Oxford: Oxford University Press).

Benson, Michael T. (1997) Harry S. Truman and the Founding of Israel (Westport, Connecticut: Praeger).

Bierbrier, Doreen (1970) 'The American Zionist Emergency Council: An Analysis of a Pressure Group', American Jewish Historical Quarterly 60 (1), pp. 82-105. 
Breitman, Richard (1996a) 'The Failure to Provide a Safe Haven for European Jewry,' in Verne W. Newton (ed.) FDR and the Holocaust (New York: St. Martin's).

(1996b) 'Roosevelt and the Holocaust,' in Verne W. Newton (ed.) FDR and the Holocaust (New York: St. Martin's).

Davidson, Lawrence (2010) 'Truman the Politician and the Establishment of Israel,' Journal of Palestine Studies 39 (4), pp. 28-42.

Devine, Michael; Watson, Robert P; Wolz, Robert J. (eds) (2005) Israel and the Legacy of Harry S. Truman, The Truman Legacy Series, Volume 3 (Missouri: Truman State University Press).

Evensen, Bruce J. (1992) 'Truman, Palestine and the Cold War,' Middle Eastern Studies 28 (1), pp. 120-156

Freidel, Frank; Sidey Hugh (2006) "Harry S. Truman," The Presidents of the United States of America,' White House Historical Association. Accessed 25 August 2018. <https://www.whitehouse.gov/about-the-white-house/presidents/harry-s-truman/>

Freund, Paul A. (1996) 'Felix Frankfurter (1882-1965)', The American Jewish Year Book 67, pp. 31-36

Goldenberg, Suzanne (2003) 'Discovery of Truman diary reveals attack on Jews,' The $\begin{array}{llllll}\text { Guardian, } & 12 & \text { July. } & \text { Accessed } & 17 & \text { August }\end{array}$ <https://www.theguardian.com/world/2003/jul/12/books.usa>

Halperin, Samuel and Oder, Irvin (1962) 'The United States in Search of a Policy: Franklin D. Roosevelt and Palestine,' The Review of Politics 24 (3), pp. 320-341.

Judis, John B. (2014) 'Seeds of Doubt', The New Republic, January 16. Accessed 27 August $2018<$ https://newrepublic.com/article/116215/was-harry-truman-zionist>

Kidd, Geraldine (2017) Eleanor Roosevelt: Palestine, Israel, and Human Rights (Abingdon: Routledge).

Kidd, Geraldine (2011) 'Eleanor Roosevelt's Blindspot: The fight for Palestine,' The Boolean: Snapshots of Doctoral Research at University College Cork, pp.107-111. Accessed 15 August 2018. <http://publish.ucc.ie/boolean/2011/00/Kidd/24/en>

Koch, Cynthia (2016) 'FDR's Last Personal Diplomacy: Ibn Saud and the Quest for a Jewish Homeland,' New York Times, September 29. Accessed 10 August 2018. http://fdrfoundation.org/fdrs-last-personal-diplomacy-ibn-saud-and-the-quest-for-a-jewishhomeland/.

Lichtman, Allan J. (2013) FDR and the Jews (Massachusetts: Harvard University Press).

Lilienthal, Alfred M. (1999) 'Remembering General George Marshall's Clash with Clark Clifford over Premature Recognition of Israel,' Washington Report on Middle Eastern Affairs (June), pp. 49-50. Accessed 27 August 2018 <https://www.wrmea.org/1999- 
june/remembering-general-george-marshalls-clash-with-clark-clifford-over-prematurerecognition-of-israel.html>

Lippman, Thomas W. (2005) 'The Day FDR Met Saudi Arabia's Ibn Saud,' The Link 38 (2), pp. 1-14.

McBride, David (2005) 'For all the Wrong Reasons?: Re-evaluating Truman, Domestic Influences, and the Palestine Question,' DOMES 14 (2), pp. 27-49.

Mearsheimer, John J. and Walt, Stephen M. (2007) The Israel Lobby and U.S. Foreign Policy (Toronto: Viking Canada)

Medoff, Rafael (2015) 'FDR's Retreat on Zionism-and What it Means Today,' Wayman Institute, May. Accessed 5 August 2018. <http://new.wymaninstitute.org/2015/05/fdrs-retreat-on-zionism-and-what-it-means-today/>

(2013) "Obama, FDR and Zionism," The Jerusalem Post, March 18. Accessed 5 August 2018. https://www.jpost.com/Opinion/Op-Ed-Contributors/Obama-FDRand-Zionism-306870.
Newport, Frank (2015) 'Historical Review: Americans' Views on Refugees Coming to U.S.' Gallup News, November 19. Accessed 25 August 2018. https://news.gallup.com/opinion/polling-matters/186716/historical-review-americans-views- refugees-coming.aspx.

Ovendale, Ritchie (1998) Anglo-American Relations in the Twentieth Century (London: Palgrave Macmillan).

(2015) The Origins of the Arab Israeli Wars (Abingdon: Routledge).

Parzen, Herbert (1974) The Roosevelt Palestine Policy, 1943-1945: An Exercise in Dual Diplomacy (Cincinnati: American Jewish Archive).

Perry, Mark (2010) 'Petraeus wasn't the first,' Foreign Policy, 2 April. Accessed 18 August 2018. https://foreignpolicy.com/2010/04/02/petraeus-wasnt-the-first/.

Pops, Gerald M. (2013) 'Marshall, the Recognition of Israel and Anti-Semitism,' The George C. Marshall Foundation. Accessed 20 August 2018. https://www.marshallfoundation.org/library/digital-archive/marshall-recognition-israel-antisemitism/

Radosh, Allis; Radosh, Ronald (2009) A Safe Haven: Harry S. Truman and the Founding of Israel (New York: HarperCollins)

Rosenfield, Geraldine (1947-1948) Zionist Activities, The American Jewish Year Book 49 (5708), pp. 244-265.

Saad, Lydia (2017) 'Gallup Vault: Americans Backed 1947 Palestine Partition Plan,' Gallup News, November 29. Accessed 19 August 2018, https://news.gallup.com/vault/222974/gallup-vault-americans-backed-1947-palestinepartition-plan.aspx. 
Snetsinger, John (1974) Truman, the Jewish Vote, and the Creation of Israel (Stanford: Hoover Institution Press).

Truman, Harry S. (1947) President Harry S. Truman's 1947 Diary Book, Diary and Manual of the Real Estate Board of New York. Accessed 10 August 2018 https://www.trumanlibrary.org/diary/transcript.htm.

Truman, Harry S. (1956) Memoirs, Volume 2: Years of Trial and Hope (Garden City: Doubleday).

\begin{abstract}
About the Author
Dr. Selin M. Bölme is Assistant Professor at Marmara University, Institute of Middle East and Islamic Countries Studies, based in Istanbul, Turkey. Her PhD thesis, US Military Base Policy and Turkey: A Study on Incirlik Air Base, was published by Iletisim Yayınları in 2012. Dr. Bölme has extensively published on Middle East, Turkey-US Affairs, Turkish foreign policy and international security issues.
\end{abstract}

